Research Based Article

\title{
KONSELING ISLAMI UNTUK MENINGKATKAN EFIKASI DIRI PASIEN HIV/AIDS
}

\author{
Dina Hajja Ristianti * \\ STAIN Curup, Bengkulu
}

\begin{abstract}
ISLAMIC COUNSELING TO IMPROVE SELF EFFICACY OF HIVIAIDS PATIENTS. HIVIAIDS sufferers show low self efficacy that causes hypochondria which people often think about loss, loneliness and sinful feelings above all of what has been done. This causes them less emphasis on health care. Implementation of the value of Islamic religion in counseling or called Islamic counseling is very important to do because of a strong relationship between religious Islam with increase self-efficacy. This study wanted to know how self efficacy of HIVIAIDS sufferers in Rejang Lebong Regency can be improved by Islamic counseling. This research was conducted in clinic VCT RSUD Curup Rejang Lebong with the counselor as the key informant. Triangulasi is done by interviewing doctor hwo is handling patient and also companion of peer (PS). Data collection is done by interview and documentation. Futuremore the data is analyzed by doing data reduction, data presentation and conclusion and meaning. The result of research shows that Islamic Counseling is done by counselor on post test counseling by giving advice concerning Allah's greatness, His forgiveness and taubatan nashuhah that bring the patient becomes more resilient, anthusiastict with the process of treatment, more eager to fulfill worship and dayly activity.
\end{abstract}

KEYWORDS: HIVIAIDS Patients, Islamic Counseling, Self efficacy.

* Corresponding Author: Program Studi Bimbingan dan Konseling Islam, Jurusan Tarbiyah STAIN Curup; Jalan Jl. Dr. AK Gani No. 01, Curup, Dusun Curup, Curup Utara, Kabupaten Rejang Lebong, Bengkulu, Indonesia 39119; Email: dinahajjaristianti@gmail.com

Article History: Received: 30-11-2017; Revised: 28-11-2017; Accepted: 05-1-2018

Permalink: http://ijec.ejournal.id/index.php/counseling/article/view/29

How to cite (APA): Ristianti, D. H. (2018). Konseling islami untuk meningkatkan efikasi diri pasien HIVIAIDS. Indonesian Journal of Educational Counseling, 2(1), 113-130.

This is an open access article distributed under the terms of the Creative Commons Attribution 4.0 International License, which permits unrestricted use, distribution, and reproduction in any medium, provided the original work is properly cited. @ 2018, Dina Hajja Ristianti.

\section{PENDAHULUAN}

Komisi Penanggulangan AIDS (KPA) Rejang Lebong melansir fakta bahwa kasus penderita HIV/AIDS di Rejang Lebong mengalami peningkatan setiap tahunnya. Berdasarkan data yang dimiliki, KPA Rejang Lebong mencatat, sejak Januari hingga Agustus 2017, jumlah pengidap HIV/AIDS berjumlah 81 orang, 
atas penambahan 2 kasus baru jumlah pengidap HIV/AIDS di Kabupaten Rejang Lebong menjadi 83 orang (Septiadi, 2017).

Berbagai macam reaksi yang terjadi ketika seseorang mengetahui dirinya terinveksi HIV/AIDS seperti shock, stres, cemas, ketegangan batin, emosional, putus asa, takut, merasa harga diri rendah, ketidakberdayaan, dan sebagainya (Amaya, 2004:3) Reaksi lain berupa penolakan setelah menerima hasil tes reaktif atau positif. Penolakan terjadi karena merasa tidak mungkin terkena HIV/AIDS, merasa bahwa dirinya orang baik-baik dan tidak pernah melakukan hal-hal menyimpang yang mengarah pada terkenanya HIV/AIDS. Orang dengan HIV/AIDS (ODHA) merasa tidak memiliki pandangan hidup ke depan serta beranggapan bahwa bunuh diri adalah hal yang terbaik. Jika gangguan-gangguan emosional dan ketegangan batin terjadi terus-menerus, maka hal demikian akan menimbulkan kesehatan mental ODHA semakin terganggu (Kartono, 2000, 21).

Yesi Ariani (2011) menjelaskan salah satu model perawatan penyakit kronis yang dikembangkan saat ini adalah The Chronic Care Model (CCM) yaitu model perawatan pasien yang menitikberatkan pada interaksi pasien yang terinformasi dan aktif dengan suatu tim kesehatan yang proaktif dan siap melayani. Hal ini berarti hubungan pasien yang termotivasi dan memiliki pengetahuan serta berkeyakinan untuk membuat keputusan mengenai kesehatan mereka dengan tim yang mampu memberikan informasi, motivasi dan sumber-sumber perawatan dengan kualitas yang baik sangat diperlukan. Berdasarkan konsep ini, pasien dengan penyakit kronis membutuhkan dukungan untuk mendapatkan informasi, pengetahuan dan mempertahankan status kesehatannya seoptimal mungkin. Dengan konsep ini maka untuk menangani penderita HIV/AIDS, RSUD Curup memiliki klinik Infeksi Menular Seksual (IMS) Dan Voluntary Counseling \& Testing (VCT). Berdasarkan wawancara dengan konselor di Klinik VCT ini memiliki tim ahli yang terdiri dari dokter, konselor dan tim OJT yang akan melakukan proses konseling pra testing, konseling post testing, dan testing HIV yang bersifat confidental dan secara lebih dini membantu orang mengetahui status HIV/AIDS. Di klinik VCT ini, pasien HIV/AIDS akan mendapatkan pelayanan dampingan secara terstruktur dan holistik agar pasien memiliki mental yang sehat dalam menjalani penyakitnya.

Pentingnya klinik VCT ini dikarenakan kondisi pasien HIV/AIDS sangat membutuhkan pendampingan. Marx, J. L (UNAIDS, 2006) menjelaskan bahwa hukuman sosial bagi penderita HIV/AIDS umumnya lebih berat bila dibandingkan dengan penderita penyakit mematikan lainnya. Hukuman sosial atau stigma oleh masyarakat di berbagai belahan dunia terhadap pengidap AIDS terdapat dalam berbagai cara, antara lain tindakan-tindakan pengasingan, penolakan, diskriminasi, dan penghindaran atas orang yang diduga terinfeksi HIV. Stigma ini 
menjadikan kondisi psikologis para penderita bermasalah. Jeffrey, et al (2006, p. 157) menjelaskan bahwa pasien yang menderita AIDS memperlihatkan keyakinan diri (self efficacy) rendah yang akan menyebabkan penderita mengalami hypochondria, dimana penderita seringkali memikirkan mengenai kehilangan, kesepian dan perasaan berdosa di atas segala apa yang telah dilakukan sehingga menyebabkan mereka kurang menitik beratkan langkah-langkah penjagaan kesehatan dan kerohanian mereka. Seorang pasien yang telah didiagnosis HIV positif dan mengetahuinya, kondisi mental penderita akan mengalami fase yang sering disingkat SABDA (Shock, Anger, Bargain, Depressed, Acceptance).

Salah satu hal terpenting di klinik VCT ini adalah membangun semangat para pasien HIV/AIDS untuk terus melakukan pengontrolan berobat. Dalam proses pengobatan di klinik VCT, pasien HIV/AIDS merasa kejenuhan karena harus meminum obat setiap hari untuk menekan pertumbuhan virus yang ada dalam tubuhnya meskipun penyakit tersebut sampai saat ini belum ditemukan obatnya (Hidayanti, 2012, p. 82). Kejenuhan berobat ini erat kaitannya dengan keyakinan diri (self efficacy) pasien HIV/AIDS. Pender menjelaskan bahwa self efficacy adalah keyakinan individu akan kemampuannya untuk mengatur dan melakukan perilaku yang mendukung kesehatannya berdasarkan pada tujuan dan harapan yang diinginkannya. Efikasi diri membantu seseorang dalam menentukan pilihan, usaha untuk maju, serta kegigihan dan ketekunan dalam mempertahankan tugas-tugas yang mencakup kehidupan mereka (Tomey, dkk, 2006). Jika self efficacy tinggi maka pasien akan menetapkan tujuan yang tinggi dan berpegang teguh pada tujuannya. Sebaliknya, seseorang yang memiliki efikasi diri yang lemah akan berkomitmen lemah pada tujuannya, sehingga terjadi ketidakpatuhan terhadap perawatan dirinya. Efikasi diri mendorong proses kontrol diri untuk mempertahankan prilaku yang dibutuhkan dalam mengelola perawatan diri (Ariani, 2011).

Wulandari (2006) menjelaskan bahwa self efficacy dapat diperoleh, diperkuat atau dilemahkan melalui persuasi sosial. Pada kondisi yang tepat persuasi dari orang lain dapat memengaruhi efikasi diri. Kondisi itu adalah rasa percaya kepada pemberi persuasi, dan sifat realistik dari apa yang dipersuasikan. Bantuan konseling kepada pasien HIV/AIDS merupakan bantuan yang diberikan konselor kepada pasien dengan mengedepankan komunikasi persuasi yang penuh empati. Hasil penelitian yang dilakukan oleh Flickinger et al (2016) terhadap dokter dan pasien HIV/AIDS dimana komunikasi dokter yang penuh empati akan meningkatkan kepatuhan pasien dalam proses pengobatan.

Penerapan nilai agama Islam dalam meningkatkan self efficacy sangat penting dilakukan karena adanya hubungan yang kuat antara keyakinan beragama (Islam) dengan peningkatan self efficacy itu sendiri, seperti penelitian 
Farras et al (2013) menunjukkan bahwa ada hubungan positif dan signifikan antara komitmen beragama (Islam) dengan parenting self efficacy $(r=+0,475$; $\mathrm{n}=69 ; \mathrm{p}<0,01$, one tail) dimana artinya semakin tinggi religious islam maka semakin tinggi pula parenting self efficacy, begitu pula sebaliknya. Dari penelitian ini disimpulkan bahwa hubungan positif ajaran Islam dengan self efficacy ini dikarenakan beberapa alasan. Salah satunya, adalah Islam menyediakan cara dalam mengatasi stress, seperti konsep religious coping yang dikemukakan oleh Pargement. Pargement menyatakan bahwa agama dapat membantu individu dalam mengatasi stress melalui dukungan spiritual dari Tuhan, dukungan dari komunitas agaman dan pengkajian ulang stressor melalui sudut pandang agama sehingga menghasilkan penilaian positif serta ritual-ritual keagamaan. Menueurtnya, secara umum agama berperan dalam memberikan sumber daya kognitif dan perilaku untuk melakukan coping terhadap sumber stress dalam berbagai konteks kehidupan.

Penerapan nilai-nilai religius Islam dalam konseling disebut dengan konseling islami (Islamic counseling). Konseling islami menurut Aunur Rahim Faqih (2001) adalah proses pemberian bantuan terhadap individu agar mampu hidup selaras sesuai dengan ketentuan dan petunjuk Allah SWT, sehingga dapat mencapai kebahagiaan hidup di dunia dan akhirat. Pemilihan konseling dengan memfokuskan pada agama Islam belum banyak dilakukan. Padahal penduduk Indonesia didominasi oleh penganut agama Islam. Berdasarkan wawancara dengan konselor di klinik VCT Rejang Lebong bahwa semua pasien HIV/AIDS yang datang ke klinik VCT Rejang Lebong adalah beragama Islam. Penelitian berkenaan dengan pasien HIV/AIDS masih didominasi oleh ilmu-ilmu psikologi Barat, sedangkan dalam perspektif Islam tidak banyak ditemukan. Peneliti-peneliti dalam IImu Sosial hendaknya juga mulai meneliti bagaimana tradisi-tradisi dari agama Non-Barat seperti Islam mempengaruhi kehidupan (Farras et al, 2013). Maka dari proses konseling yang dilakukan oleh konselor di klinik VCT RSUD Curup, peneliti ingin melihat seperti apa keterlibatan kaidah-kaidah atau nilai-nilai agama Islam dalam muatan proses konseling yang dilakukan konselor dalam meningkatkan Self efficacy penderita HIV/AIDS di Rejang Lebong.

Terkait dengan Pelayanan Konseling Islami, hakekat layanan koseling islami adalah upaya membantu individu belajar mengembangkan fitrah-iman dan dan atau kembali kepada fitrah-iman, dengan cara memberdayakan (enpowering) fitrah-fitrah (jasmani, rohani nafs, dan iman) mempelajari dan melaksanakan tuntunan Allah dan Rasul-Nya, agar fitrah-fitrah yang ada pada individu berkembang dan berfungsi dengan baik dan benar. Pada akhirnya diharapkan agar individu selamat memperoleh kebahagiaan yang sejati di dunia dan akhirat (Sutoyo, 2013). 
Tujuan yang ingin dicapai melalui layananan konseling islami adalah agar fitrah yang dikaruniakan Allah kepada individu bisa berkembang dan berfungsi dengan baik, sehingga menjadi pribadi yang khaffah, dan secara bertahap mampu mengaktualisasikan apa yang diimaninya itu dalam kehidupanya sehari-hari, yang tampil dalam bentuk kepatuhan terhadap hukum-hukum Allah dalam melaksanakan kekhalifahan di bumi, dan ketaatan dalam beribadah dengan mematuhi segala perintah-Nya dan menjauhi segala larangan-Nya. Dengan kata lain, tujuan konseling model ini adalah meningkatkan iman, Islam, dan ihsan individu yang dibimbing hingga menjadi pribadi yang utuh. Akhirnya diharapkan mereka bisa hidup bahagia di dunia dan di akhirat, hal ini sangat berbeda dengab konseling konvensional yang hanya tertuju pada kehidupan di sini dan pada saat ini (here and now).

Selain itu, konseling Islam mampu meningkatkan spiritual, dimana spiritualitas merupakan kebutuhan dasar manusia. Sebagaimana dikemukakan oleh Howard Clinebell dalam tulisannya yang berjudul "The Role of Religion in the Prevention and Treatment of Addictions the Growth Counseling Perspective" pada konferensi pertama "Pan Pacific on Drugs and Alchoholism", bahwa pada dasarnya setiap manusia memiliki kebutuhan dasar spiritual ("basic spiritual needs") tidak hanya bagi mereka yang beragama, tetapi bagi mereka yang sekuler sekalipun (Hawari, 2008).

Pemenuhan terhadap kebutuhan spiritualitas ternyata memberikan kontribusi yang maha penting dalam perjalanan hidup orang dengan HIV/AIDS. Hal ini didukung dengan berbagai penelitian antara lain oleh Woods dari University of Miami untuk mengetahui hubungan antara fungsi kekebalan tubuh pada pasien HIV positif dengan komitmen agama. Pasien yang aktif menjalankan peribadatan keagamaan menunjukkan jumlah CD4+ dan presentase CD4+ (Thelperinducer cells) meningkat, yang berarti bahwa sistem kekebalan tubuh berjalan dengan baik. Dengan demikian progresivitas penyakit dapat dihambat sehingga umur pasien menjadi lebih panjang (Hawari, 2008). Penelitian lain dilakukan di Yale University School of Medicine terhadap 90 pasien dengan HIV positif untuk mengetahui reaksi mereka terhadap kecemasan menghadapi kematian, keputusasaan untuk mengakhiri kehidupan, tingkat religi, dan adanya rasa bersalah/berdosa terhadap infeksi HIV yang dideritanya. Berdasarkan survei tersebut diperoleh data bahwa mereka yang aktif melakukan kegiatan keagamaan kecemasan/ketakutan terhadap kematian sangat rendah. Kecemasan/ketakutan menghadapi kematian terdapat $25 \%$ pasien yang merasa bahwa penyakit yang dideritanya itu sebagai hukuman. Survei tersebut menyimpulkan bahwa infeksi HIV menjadikan pasien lebih religius, mereka yakin bahwa Tuhan Maha Pengampun, Maha Penyayang, sehingga mereka dapat menerima penyakit yang dideritanya dengan kematian lebih awal (Hawari, 2008). Hasil kajian di atas telah 
membuktikan bahwa spiritualitas/religiusitas mampu menjawab dinamika psikologis yang dihadapi penderita HIV/AIDS. Dimana menurut Kubler Ross (Potter \& Perry, 2005, p. 568) setiap individu yang terkena penyakit kronis akan mengalami beberapa fase mulai penolakan (denial), marah (anger), tawar menawar (bargaining), depresi (depression), dan menerima (acceptance). Kesehatan spiritual adalah keharmonisan saling kedekatan antara diri dengan orang lain, alam, dan dengan kehidupan yang tertinggi (Potter \& Perry, 2005).

Konseling HIV/AIDS merupakan wawancara yang bisa dikatakan sangat rahasia antara klien dan pemberian layanan (konselor) yang bertujuan membuat orang tersebut mampu menyesuaikan diri dengan stres dan mampu membuat keputusan terkait dengan HIV/AIDS (Nursalam dan Ninuk, 2009:73). Proses konseling ini termasuk evaluasi terhadap resiko penularan HIV dan memfasilitasi pencegahan perilaku seseorang yang beresiko tertular HIV/AIDS serta evaluasi diri ketika klien menghadapi hasil tes HIV positif (agus P, 2009:120). VCT adalah suatu pembinaan dua arah atau dialog yang berlangsung tak terputus antara konselor dan kliennya dengan tujuan untuk mencegah penularan HIV, memberikan dukungan moral, informasi, serta dukungan lainnya kepada ODHA, keluarga dan lingkungannya. Jadi VCT memberikan konseling secara menyeluruh yatu dari awal pra test, pasca tes dan konseling berkelanjutan bagi klien agar mampu beradaptasi dengan penyakitnya bahkan memfasilitasi konseling antara klien dan keluarganya. Nursalam dan Ninuk (2009:76) menjelaskan bahwa konseling HIV/AIDS pada dasarnya sama dengan konseling pada umumnya. Namun konseling HIV/AIDS menjadi unik dibanding konseling lainnya karena :

a) Membutuhkan pengetahuan yang luas tentang infeksi menular seksual (IMS) dan HIV/AIDS

b) Membutuhkan pembahasan mengenai praktik seks yang bersifat pribadi.

c) Membutuhkan pembahasan tentang kematian atau proses kematian.

d) Membutuhkan kepekaan konselor dalam menghadapi perbedaan pendapat dan nilai yang mungkin sangat bertentangan dengan nilai yang dianut oleh konselor itu sendiri.

e) Membutuhkan ketrampilan pada saat memberikan hasil HIV yang positif.

f) Membutuhkan ketrampilan dalam menghadapi kebutuhan pasangan anggota keluarga klien.

Albert Bandura (1986) menjelaskan bahwa Efikasi diri atau keyakinan kebiasaan diri itu dapat diperoleh, diubah, ditingkatkan atau diturunkan melalui salah satu atau kombinasi empat sumber, yakni pengalaman menguasai sesuatu prestasi 
(performance accomplishment), pengalaman vikarius (vicarious experience), persuasi sosial (social persuation), dan pembangkitan emosi (emotional/physiological states). Begitupun dengan pasien HIV/AIDS bahwasanya self efficacy mereka dapat ditingkatkan melalui konseling islam yang penuh empati. Karakteristik individu yang memiliki Efikasi Diri yang tinggi adalah ketika individu tersebut merasa yakin bahwa mereka mampu menangani sesecara efektif peristiwa dan situasi yang mereka hadapi, tekun dalam menyelesaikan tugas-tugas, percaya pada kemampuan diri yang mereka miliki, memandang kesulitan sebagai tantangan bukan ancaman dan suka mencari situasi baru, menetapkan sendiri tujuan yang menantang dan meningkatkan komitmen yang kuat terhadap dirinya, menanamkan usaha yang kuat dalam apa yang dilakuakanya dan meningkatkan usaha saat menghadapi kegagalan, berfokus pada tugas dan memikirkan strategi dalam menghadapi kesulitan, cepat memulihkan rasa mampu setelah mengalami kegagalan, dan menghadapi stressor atau ancaman dengan keyakinan bahwa mereka mampu mengontrolnya (Ariani, 2011)

\section{METODE}

Penelitian ini, diajukan untuk menganalisis dan mengungkapkan peningkatan Self efficacy penderita HIV/AIDS melalui Konseling Islami. Dalam mengumpulkan, mengungkapkan berbagai masalah dan tujuan yang hendak dicapai maka, penelitian ini dilakukan dengan pendekatan studi kualitatif deskriptif. Menurut Sugiyono (2008) penelitian kualitatif deskriptif adalah metode penelitian yang berlandaskan pada filsafat postpositivisme yang biasanya digunakan untuk meneliti pada kondisi objektif yang alamiah dimana peneliti berperan sebagai instrumen kunci.

Informan kunci yang akan dibagi menjadi informan kunci dan informan pelengkap. Informan dalam penelitian ini antara lain; Konselor di Klinik VCT, dokter yang menangani penderita HIV/AIDS sedangkan informan lainnya adalah orang-orang dengan interaksi dengan penderita HIV/AIDS yang tinggi seperti pendamping pasien HIV/AIDS. Ada dua jenis data dikategorikan berdasarkan fungsinya, yakni data primer dan data sekunder

Adapun teknik pengumpulan data yang dilakukan dalam penelitian ini adalah wawancara dan Studi Dokumentasi. Adapun kisi-kisi wawancara dalam tabel 1 berikut ini:

Tabel 1. Kisi-kisi Wawancara

\begin{tabular}{ll}
\hline Aspek & Indikator \\
\hline Konseling Islam & 1. Minat Konselor dalam melaksanakan konseling islam \\
\hline
\end{tabular}




\begin{tabular}{lll}
\hline & 2. & Materi konseling islam \\
& 3. & Respon klien/pasien \\
\hline Self efficacy & 1. & Ketabahan pasein menghadapi penyakit \\
& 2. & Ketekunan pasien dalam berobat \\
& 3. & Aktivitas ibadah pasien \\
& 4. & Aktivitas keseharian pasien \\
\hline
\end{tabular}

Studi dokumentasi diarahkan pada pengumpulan data dari laporan yang ada diklinik VCT RSUD Curup. Untuk mejawab masalah penelitian dan memperoleh makna sebenarnya dari fenomena yang diteliti, perlu dilakukan analisis data-data yang telah dihimpun. Analisis data dilakukan dengan cara reduksi data, penyajian data dan pemaknaan atau penarikan kesimpulan.

\section{HASIL DAN PEMBAHASAN}

Klinik VCT Rejang Lebong terdiri dari beberapa orang ahli yang memiliki peran masing-masing yang bekerja dalam satu tim. Tim ini terdiri dari Direktur RSUD Curup, dr. A. Khalik R. Muhibta, Sp. PD sebagai penasehat tim VCT RSUD Curup. Kabid Pelayanan RSUD Curup, dr. Honey Rossa Nita sebagai penanggung jawab tim VCT RSUD Curup. Dokter Sp. OG, dr. Aminullah Djuang, Sp. OG sebagai ketua tim VCT RSUD Curup. Kasi pelayanan Medis, Nur Aisyah, Am. Keb sebagai konselor di klinik VCT RSUD Curup. Staf Laboratorium, Siti Aisyah, Am. Keb sebagai tenaga laboratorium di klinik VCT RSUD Curup. Staf Laboratorium, Mardiani, AM sebagai tenaga laboratorium di klinik VCT RSUD Curup dan staf bidang pelayanan, Julian Mardianto, SKM sebagai pencatatan dan pelaporan di klinik VCT RSUD Curup.

Pelaksanaan layanan VCT di RSUD Curup berdasarkan hasil wawancara peneliti dengan konselor di klinik VCT yaitu ibu Nur Aisyah, dikemukakan bahwa:

"Klien datang pada tahap awal ini jika penderita HIVIAIDS (ODHA) menyadari sendiri bahwa dirinya sedang mengalami gejala-gejala HIVIAIDS atau mereka mendapat rekomendasi dari pihak puskesmas atau dokter tempat penderita berobat. Namun, tidak semua penderita HIVIAIDS mau datang sendiri memeriksakan dirinya ke klinik VCT ini, biasanya konselor dan tim VCT akan bergerak sendiri ke lapangan untuk mendeteksi orang-orang dengan tingkat esiko tinggi untuk tertular HIVIAIDS, biasanya tim melakukan pemeriksaan lansung terhadap para waria yang bekerja di salon-salon yang berada di Rejang Lebong. Peran konselor sangat dominan pada tahap ini. Bagi mereka yang kemungkinan besar sedang mengalami gejala-gejala HIVIAIDS dimana bisa dilihat dari fisik yang biasanya sangat kurus dan sering batuk-batuk.

Konseling pre tes kepada mereka yang tinggi resiko tertular HIV/AIDS dilakukan dalam rangka memberikan upaya pencegahan dengan mempromosikan perubahan perilaku seksual dalam menurunkan penularan HIV. 
Mereka yang beresiko tinggi tertular HIV/AIDS yang telah mendapatkann konseling dari konselor VCT memiliki pengertian yang kuat tentang tata nilai dan aktivitas seksual. Dari wawancara dengan konselor dikemukakan bahwa:

"Pada tahap ini konselor akan memberikan kondom gratis sebagai langkah pencegahan. Biasanya pemberian informasi bagi mereka yang beresiko ini dilakukan konselor empat mata karena memang diminta dari pihak klien tersebut dengan alasan menjaga privasi. Mereka yang tinggi resiko tertular HIVIAIDS ini (waria, gay dan ibu rumah tangga yang menjadi korban) juga diarahkan untuk memerikasakan diri untuk melihat status tertular atau tidak dengan meyakinkan dan memberikan penjelasan-penjelasan tentang pentingnya pemeriksaan. Layanan konseling pre tes ini, juga melibatkan layanan mobile dengan fasilitas online untuk memudahkan komunikasi antara konselor dengan pihak klien.

Mereka yang telah memeriksa antibodi dan ternyata positif HIV/AIDS akan mendapatkan pelayanan konseling pasca tes dengan konselor VCT. Dari wawancara dengan konselor dikemukakan bahwa:

"Disinilah hubungan dekat dan mendalam antara klien dan konselor terjadi melalui proses konseling. Pada konseling pasca tes ini klien diajak untuk menerima dengan lapang dada terhadap penyakit yang ia derita. Ungkapan depresi, putus asa, malu sampai ada yang ingin mengakhiri hidupnya. Klien-klien ini pun dikonselingi dengan cara yang berbeda sesuai dengan tingkat keterbukaan klien dengan konselor".

Pelaksanaan konseling islam oleh konselor di klinik VCT RSUD Curup dimana konselor melibatkan unsur atau nilai-nilai islam bagi pasien ODHA yang digunakan untuk menumbuhkan semangat hidup mereka. Hal ini merupakan dorongan naluri dari konselor sebagai seorang muslim. Dari wawancara dengan konselor dikemukakan bahwa:

"Karena kita sama-sama muslim dimana ada rasa tanggung jawan saya untuk mengingatkan pasien ODHA akan tugasnya sebagai seorang hamba Allah. Saya tidak memaksa tetapi hanya ingin mengajak mereka untuk berfikir tentang hal lain yang akan membuat mereka lebih tenang".

Konselor saat menemui klien dengan tingkat keterbukaan yang tinggi dan penerimaan terhadap konselor juga tinggi, maka konselor akan mengajak klien untuk memikirkan akhirat yang akan dilewati setelah mati. Dari wawancara dengan konselor dikemukakan bahwa:

"Klien akan saya ajak memikirkan tentang kehidupan akhirat. Biasanya yang mau diajak ngobrol tentang ini adalah para ibu rumah tangga yang menjadi korban karena tertular dari suaminya. Atau juga dari para gay yang lebih tinggi tingkat keterbukaannya dengan konselor dibandingkan dengan para waria. Kalau tingkat penerimaan klien terhadap konselor tinggi biasanya mereka akan serius menanggapi pembicaraan konselor tentang akhirat. Saya selalu bilang kepada para pasien bahwa tugas kita tidak sebatas hanya di dunia saja. Tugas kita akan berlanjut dan malah akan lebih kekal di akhirat kelak. Alam 
akhirat hanya dua yaitu surga dan neraka. Tempat kita diakhirat terantung dari amalan yang kita buat di dunia"

Selain mengajak klien memikirkan tentang Allah swt dan juga alam akhirat, konselor juga mengajak mereka untuk memikirkan hikmah sakit dalam Islam. Dari wawancara terungkap bahwa:

"Biasanya saya akan mengajak mereka memikirkan bahwa orang yang paling baik bukanlah orang yang tidak melakukan dosa. Orang yang paling baik itu adalah orang yang mau bertaubat dari kesalahan-kesalahannya. Allah maha pengampun melebihi makhluk lain dalam memaafkan. Sakit adalah kesempatan waktu yang diberikan Allah agar kita bisa bertaubat dari segala dosa. Taubat akan selalu diterima Allah selagi denyut nadi masih berdetak"

Selain itu juga, konselor mengajak klien untuk terus berupaya menerima dengan positif penyakit yang ia derita. Dalam hal ini konselor mengajak klien agar memikirkan tentang kebesaran Allah dan maha pengampun Allah serta taubatan nashuhah. Dari wawancara dikemukakan bahwa:

"Saya mengajak klien untuk memikirkan kebesaran Allah bahwa Allah maha pengampun. Semua dosa dan kesalahan apapun akan Allah ampuni. Tinggal kita sendiri yang mau atau tidak memhon ampunan kepada-Nya."

Konselor selalu memberikan motivasi agar klien mau terus berobat. Biasanya konselor memberikan contoh-contoh tentang penderita ODHA yang berhasil lama hidup. Dari wawancara dikemukakan bahwa:

"Saya biasanya akan memberikan contoh pasien yang berhasil hidup dengan mengidap HIVIAIDS. Malah saya berikan contoh ada satu orang pasien HIVIAIDS yang ternyata istri dan dua orang anaknya negative terkena virus HIVIAIDS."

Respon klien-klien terhadap upaya konselor melibatkan unsur atau nilai-nilai keislaman di klinik VCT RSUD Curup, berbagai macam. Dari wawancara terungkap bahwa:

"Respon dari klien terhadap upaya saya mengajak mereka ngobrol tentang keislaman ya bermacam-macam. Ada yang mau mendengar dan merepon positif terhadap apa yang saya utarakan. Ada yang merespon yang sepertinya ia lebih tahu tentang Islam dibanding dengan saya, ini biasanya pasien-pasien waria. Mereka selalu berdalih bahwa ia adalah wanita yang terperangkap ditubuh pria. Namun bagi pasien ibu rumah tangga dan gay mereka cenderung senang untuk diingatkan tentang keislaman yang bisa jadi mereka tidak pernah tahu"

Peningkatan self efficacy pasien ODHA di klinik VCT RSUD Curup ini dapat dilihat dari aktivitas control mereka di klinik VCT RSUD Curup. Dari wawancara dengan konselor terungkap bahwa: 
"Saya berusaha untuk mengingatkan mereka bahwa betapa besar kasih sayang Allah swt terhadap hamba-hamba-Nya. Para pasien pun merespon dengan berbagai cara. Bagi ibu rumah tangga biasanya mereka lebih mudah untuk kita ajak ngobrol tentang hal itu. Mereka mau menerima apa yang konselor katakan. Terlebih juga gay. Para penyuka lelaki ini atau sering disebut LSL (lelaki suka lelaki) ini mudah diajak untuk ngobrol tentang keislaman. Biasanya gay akan merespon dengan positif dan terbuka. Malah ada satu orang pasien yang diawal sangat depresi dan ingin bunuh diri saat tahu ia positif mengidap HIVIAIDS, setelah konselor ajak ngobrol tentang kasih sayang Allah, malah pada konseling berikutnya ia bercerita kalau ia bersyukur dengan penyakit yang ia derita tersebut. Setelah ia konseling kemarin ia menjadi sangat bersemangat mempelajari keislaman. la senang solat berjamaah di masjid dan senang berkumpul dengan para jamaah tabligh. Perubahan fisik pun sangat bisa dilihat, dimana wajah dan badannya lebih berisi dan bersih dibandingkan dengan kondisi di awal ia datang ke klinik VCT. la pun rutin berobat dan nampak lebih pasrah serta tenang jika datang dalam kondisi yang sudah drop. Keluarga nya pun mengakui adanya perubahan tersebut"

Hal ini juga diungkapkan oleh dokter yang menangani ODHA. Dari wawancara dengan dokter terungkap bahwa:

"Pasien ODHA yang rutin berobat memperlihatkan sikap yang berbeda. Mereka kelihatan lebih tenang dan sehat dibanding dengan sebelum mereka konseling di klinik VCT. Saya yakin perubahan ini karena keterlibatan konselor yang penuh empati dan mau menerima klien apa adanya. Mau mengingatkan klien akan agama nya. Saya juga sering memotivasi mereka agar mereka selalu meminta perlindungan Allah melalui ibadah. Saya yakin jika nilai agama mereka kuat, maka kuat juga keyakinan dirinya bahwa ia mampu menghadapi penyakit yang ia derita"

Selain ketekunan ODHA dalam berobat, self efficacy dapat juga dilihat dari semangat hidup ODHA dalam sehari-hari. Berdasarkan wawancara dengan pendamping sebaya ODHA dikemukakan bahwa:

"ODHA yang sering datang konseling dengan konselor terlihat lebih semangat dalam beraktivitas. Selain lebih tekun beribadah, seperti sering datang ke masjid untuk solat berjamaah, rutin solat lima waktu. Mereka juga berusaha memperbaiki diri, seperti lebih dekat dengan keluarga dan lebih senang membantu mengatasi kesulitan orang lain".

Adapun kendala konselor dalam membimbing pasein HIV/AIDS ini adalah kurangnya pengetahuan konselor tentang agama. Dari wawancara terungkap bahwa:

"Saya merasa belum bisa mengingatkan pasien dengan dikuatkann oleh dalil-dalil alquran. Seharusnya dalam mengingatkan orang lain hendaknya didukung dengan fiman Allah atu hadis-hadis sohih. Saya bukan berlatar belakang pendidikan Islam. Cuma saya hanya bisa mengingatkan tentang kebesaran Allah, indahnya taubat dan hikmah sakit sebatas saya bisa menyampaikan. Mungkin hal ini juga terkadang membuat para pasien agak kurang mau saya ajak bicara tentang keislaman. Malah terkadang saya kalah debat juga dengan waria yang ternyata mereka paham dengan persoalan agama" 
Kendala lain mungkin juga kurangnya sinergi dari orang-orang yang mendampingi mereka. Misalnya saja dengan para pendamping ODHA yang sudah ditunjuk oleh komunitas HIV/AIDS seperti LSM KIPAS Rejang Lebong. Dari wawancara terungkap bahwa:

"Para pendamping ODHA juga belum bisa mendampingi ODHA untuk mengingatkan keislaman. Saya berharap kedepan, para pendamping ODHA adalah orang-orang yang memiliki semangat membantu para ODHA dengan memiliki kapasitas keislaman yang tinggi. Sehingga ODHA bisa dingatkan dan bisa bertaubat"

Untuk memastikan ini, saya juga melakukan wawancara dengan pendamping sebaya pasien HIV/AIDS (ODHA). Dari wawancara terungkap bahwa:

"Saya mendampingi komunitas ODHA yang terdiri dari 7 orang ODHA. Saya adalah teman curhat bagi mereka dengan tujuan agar kondisi mental mereka stabil. Saya juga mengingatkan agar perilaku seksual mereka harus terus terkontrol agar tidak menularkan virus HIVIAIDS kepada orang lain. Seperti rutin meminum obat dan memakai kondom saat berhubungan intim"

Konseling di klinik VCT RSUD Curup dilakukan konselor sesuai dengan prosedur dalam pelaksanaan konseling dimana konseling HIV/AIDS merupakan wawancara yang sangat rahasia antara klien dan pemberian layanan (konselor) yang bertujuan membuat orang tersebut mampu menyesuaikan diri dengan stres dan mampu membuat keputusan terkait dengan HIV/AIDS (NUrsalam dan Ninuk, 2009). Proses konseling ini termasuk evaluasi terhadap resiko penularan HIV dan memfasilitasi pencegahan perilaku seseorang yang beresiko tertular HIV/AIDS serta evaluasi diri ketika klien menghadapi hasil tes HIV positif.

Pelayanan konseling Islam di klinik VCT RSUD Curup terhadap HIV/AIDS adalah dengan membangkitkan rasa percaya kepada Allah SWT. pasien HIV/AIDS diajak untuk membesarkan keagungan dan keampunan Allah SWT bagi mereka. Pemberian konseling islam ini dilakukan secara langsung kepada klien/pasien ODHA.

Kualitas konselor menentukan keefektifan konseling. Karenanya konselor HIV/AIDS setidaknya memiliki ciri antara lain berkeinginan untuk belajar dari pengalaman, kemampaun untuk menerima orang lain, kemampuan mendengarkan cara pandang optimis, sikap yang tidak menghakimi, kemampuan menyimpan rahasia, kemampuan memberikan dukungan, empati, memahami keterbatasan klien, mengerti keterbatasan diri sendiri dan dapat merujuk pada pihak lain (J.H Syahlan, 1997). Semua kualitas konselor tersebut sangat dibutuhkan dalam menjalankan tugas yang antara lain membantu klien menyesuaikan diri pada perubahan perilaku, dan memiliki keahlian dan kemampuan membantu klien mengatasi masalahnya. Dengan demikian pada dasarnya konselor HIV/AIDS sama dengan konselor pada umumnya yang 
diharuskan memiliki kompetensi moral, kepribadian, dan ketrampilan membantu. Dimana kompetensi sebagai konselor salah satunya diperoleh melalui pelatihan konselor profesional HIV/AIDS yang didalamnya diberikan materi tentang penyakit HIV/AIDS.

Berdasarkan penelitian yang telah dilakukan terhadap konselor di klinik VCT RSUD Curup bahwasanya mereka telah menerapkan konseling islam bagi para penderita HIV/AIDS. Hal ini perlu dilakukan karena adanya rasa tanggungjawab konselor sebagai seorang muslim terhadap pasien ODHA yang juga seorang muslim. Dengan memberikan konseling Islam, konselor ingin para penderita HIV/AIDS tidak terlalu berlarut-larut dalam kondisi tertekan atau depresi. Hasil pengakajian yang dilakukan oleh Bagian Psikiatri Rumah Sakit Umum Cipto Mangunkusumo Jakarta, yang mengungkapkan bahwa umumnya pasien dengan HIV/AIDS mempunyai risiko tinggi untuk bunuh diri. Diperkirakan, sepertiga pasien HIV/AIDS pernah mempertimbangkan untuk meminta bantuan tenaga medis mengakhiri hidupnya (Hidayanti, 2012). Begitupun dengan klien-klien yang datang untuk konseling di klinik VCT RSUD Curup juga mengalami hal yang sama, karena depresi, merasa tidak berguna karena sudah tidak sehat dan serupawan dahulu lagi. Hal inilah yang mendorong konselor untuk memotivasi pasien agar keluar dari keterpurukan dan depresi melalui konseling islami.

Tabel 2. Tahapan Psikologis dan Tindakan Pendampingan Bagi ODHA

\begin{tabular}{ll}
\hline Tahapan psikologis & \multicolumn{2}{c}{ Tindakan yang dibutuhkan } \\
\hline Tahap denial & - Mengidentifikasi terhadap kematian \\
& - Mendorong pasien untuk mengekpresikan perasaaan takut \\
& menghadapi kematian dan mengeluarkan keluh-kesahnya \\
\hline Tahap kemarahan & - Memberikan kesempatan mengekspresikan marahnya \\
& - Memahami kemarahan pasien \\
\hline Tahap tawar & - Mendorong pasien agar mau mendiskusikan perasaan kehilangan \\
menawar & dan takut menghadapi kematian \\
& - Mendorong pasien untuk menggunakan kelebihan (positif) yang ada \\
& pada dirinya. \\
\hline Tahap depresi & - Memberikan dukungan dan perhatian \\
& - Mendorong pasien untuk melakukan aktivitas sehari-hari sesuai \\
& kondisi. \\
& - Membantu menghilangkan rasa bersalah, bila perlu mendatangkan \\
& pemuka agama \\
\hline tahap menerima & - Memotivasi pasien untuk mau berdoa dan sembahyang \\
& - Memberikan bimbingan keagamaan sesuai keyakinan pasien. \\
\hline
\end{tabular}

Menurut Kubler Ross (Syahlan, 1997), setiap individu yang terkena penyakit kronis akan mengalami beberapa fase mulai penolakan (denial), marah (anger), tawar menawar (bargaining), depresi (depression), dan menerima (acceptance). Selama melalui tahapan psikologi ini seseorang dengan HIV/AIDS membutuhkan 
tindakan pendampingan yang intensif bahkan konseling dimana pada tiap tahapan membutuhkan tindakan seperti disajikan pada Tabel 2.

Berdasarkan Tabel 2, terlihat bahwa pada fase-fase terakhir dibutuhkan pemenuhan penguatan dan peningkatan spiritualitas pasien. Selain pada hakikatnya spiritualitas menjadi kekuatan utama pasien menghadapi penyakitnya dengan konsekuensi dihadapkan pada kematian. Arah konseling bagi penderita HIV/AIDS adalah memberikan beragam dukungan yang dibutuhkan dalam menghadapi penyakitnya.

Dengan demikian, konseling Islam bagi pasien HIV/AIDS diarahkan pada pengembangan sikap dan ketahanan diri klien dalam berjuang melawan penyakitnya, menumbuhkan kesabaran, ketabahan dan keuletan klien untuk melakukan ikhtiar terbaik melawan penyakitnya yang secara medis sulit disembuhkan, namun sikap dan ketahanan dirinya lebih kuat dari penyakitnya itu sendiri. Untuk mencapai tujuan tersebut, konselor berusaha mengajak pasien meningkatkan keimanan kepada Allah SWT dan tekun melaksanakan ibadah sebagai cara yang efektif terjaga dari stres dan gangguan psikologis negatif lainnya.

Mendisiplinkan ibadah baik kualitas dan kuantitas secara signifikan akan membantu terciptakan ketenangan hati. Hal ini pada gilirannya membantu syaraf berkerja maksimal menghasilkan berbagai hormon yang mendorong imun tubuh alami makin meningkat. Deskripsi di atas senada dengan pendapat Utley dan Wachholtz, yang menyimpulkan berbagai riset tentang spiritualitas di kalangan penderita HIV/AIDS menunjukkan hubungan signifikan antara spiritualitas dengan perkembangan penyakit.

Konseling islam mampu membangkitkan keyakinan diri (self efficacy) penderita bahwa ia mampu menghadapi penyakit tersebut. Hal ini sejalan dengan penelitian yang dilakukan oleh Fryback (Potter \& Perry, 2005, p. 139) pasien dengan penyakit terminal mengalami ketakutan dan keresahan yang luar biasa karena dihadapkan pada kematian yang belum pasti. Dalam keadaan seperti ini, pasien yang memiliki tingkat spiritualitas tinggi, lebih mampu menghadapi kondisi ini dengan baik karena mereka mampu memaknai dengan lebih baik sakit dan sisa hidup yang harus dijalani.

Peningkatan self efficacy pasien HIV/AIDS melalui Islamic konseling adalah langkah efektif dalam membantu para pasien ODHA. Konseling yang bertujuan membangkitkan religious klien, akan menjadikan klien mampu menghadapi penyakitnya. Seperti yang dijelaskan Becher bahwa penganut agama Islam yang religious menganggap bahwa Islam adalah agama yang relevan terhadap semua aspek khidupan dan menjadi cara hidup mereka. Islam juga memberikan jawaban 
terhadap semua persoalan hidup mereka melalui alquran sebagai kitab suci sehingga membantu umatnya menhadapi persoalan hidupnya.

Melalui konseling islam, religious pasien menjadi meningkat dan begitu pun dengan self efficacy nya, dimana ia mampu mempertahankan aktivitas yang dapat menjadikan ia kuat menghadapi penyakit, rutin berobat dan akhirnya lebih tenang dalam menghadapi penyakit. Menjaga kondisi psikologis pasien adalah hal terpenting dibanding hanya sekedar meminta mereka meminum obat. Karena psikologis yang sehat menjamin pasien dapat bertahan hidup lebih lama.

Ema Hidayati (2012) menjelaskan bahwa mengajak pasien untuk mendekatkan diri pada Allah memang tidak mudah. Pasien seringkali merasa sangat berdosa karena telah melanggar agamanya sehingga mereka merasa tidak pantas beribadah. Dalam kondisi semacam ini, konselor harus mampu membesarkan hati pasien dengan mengingatkan kebesaran Allah yang Maha Pengampun, asal mereka melakukan tauban nasuha. Ungkapan yang bisa disampaikan pada pasien misalnya "Innallaha Ghofururrokhiim Allah itu akan mengampuni kalau panjenengan bertobat nasuha". Kemudian konselor membangun keyakinan pasien untuk melakukan pengobatan dengan rutin dan membangun komitmen pasien untuk tidak kembali pada kebiasaannya (melakukan perilaku seks beresiko).

Kendala lain dalam memberikan konseling Islam adalah dukungan dari pendaping ODHA. Seharusnya antara konselor dan pendamping ODHA dapat berjalan bersama-sama membangkitkan semangat hidup para ODHA melalui peningkatan pemahaman agama terutama membangkitkan keislaman ODHA. Selama ini pendamping ODHA belum mampu berperan dalam meningkatkan religious Islam ODHA. Hal ini sesuai dengan apa yang ditulis oleh Latifah, Zainuddin, \& Mulyana (2015) bahwa peran pendamping ODHA adalah sebatas sebagai fasilitator, mediator, pembela dan pelindung.

\section{SIMPULAN}

Dari hasil penelitian tentang Peningkatan Self efficacy Penderita HIV/AIDS (ODHA) melalui Islamic Counseling dapat disimpulkan bahwa: Islamic Counseling atau konseling islam dilakukan pada konseling post test, hal ini dilatarbelakangi oleh rasa tanggungjawab konselor sebagai sesama muslim, para ODHA yang ditangani sebanyak 28 orang yang beragama Islam. ODHA yang mau diajak mendengar nasehat konselor mengenai keislaman rata-rata adalah ibu rumah tangga dan gay, sedangkan waria cenderung merespon dengan mekanisme pertahanan diri. Konseling islam yang diberikan adalah mengajak pasien ODHA untuk mengingat kebesaran Allah, ampunan Allah dan taubatan nashuha. 
Peningkatan self efficacy terlihat dari keyakinan ODHA akan kemampuan mereka melewati proses berobat yang harus dilakukan rutin setiap hari. ODHA juga bertambah yakin bahwa ia mampu melakukan aktivitas sehari-hari terutama yakin terhadap kemampuan mereka untuk melaksanakan amal ibadah. Kendala yang dialami oleh konselor adalah kurangnya kemampuan mereka untuk memberikan nasehat agama yang diperkuat dengan dalil-dalil al-quran. Hal ini dikarenakan latarbelakang (backround) pendidikan mereka bukan murni dari agama. Kendala lain adalah belum kompaknya antara konselor dengan pendamping ODHA dalam memberikan konseling islami. Pendamping ODHA hanya sebagai teman curhat ODHA saja.

\section{REFERENSI}

Abimayu, S., \& Manrihu, M. T. (1996). Tehnik dan laboratorium konseling. Jakarta: Proyek Pendidikan Tinggi Dirjen Pendidikan Tinggi Departemen Pendidikan dan Kebudayaan.

Ariani, Y. (2011). Hubungan antara motivasi dengan efikasi diri pasien dm tipe 2 dalam konteks asuhan keperawatan di RSUP. H. Adam Malik Medan. (Unpublished master's thesis) Universitas Indonesia, Depok, Indonesia.

Aristiana, N. F. (2015). Pelayanan bimbingan dan konseling Islam dalam meningkatkan kesehatan mental pasien HIVIAIDS di klinik VCT rumah sakit Islam Sultan Agung Semarang. (Unpublished undergraduate's thesis) UIN Walisongo, Semarang, Indonesia.

Bandura, A. (1986). Social foundation of thought and action: A social-cognitive view. Englewood Cliffs: Prentice-Hall.

Farras A, et al. (2013). Hubungan Religius Islam dengan parenting self efficacy pada Ibu dari Toddler. (Unpublished research report) Universitas Indonesia, Depok, Indonesia.

Faqih, A. R. (2001). Bimbingan dan konseling dalam Islam. Yogyakarta: UII Press.

Flickinger, T. E., Saha, S., Roter, D., Korthuis, P. T., Sharp, V., Cohn, J., Eggly, S., Moore, R. D., \& Beach, M. C. (2016). Clinician empathy is associated with differences in patient-clinician communication behaviors and higher medication self-efficacy in HIV care. Patient education and counseling, 99(2), 220-226.

Hawari, D. (2008). Integrasi agama dalam pelayanan medik. Jakarta: Fakultas Kedokteran Universitas Indonesia. 
Hidayanti, E. (2012). Dimensi psiko-spiritual dalam praktik konseling bagi penderita HIVIAIDS di klinik Voluntary Counselling Test (VCT) rumah sakit Panti Wiloso Citarum Semarang. (Unpublished research report) IAIN Walisongo, Semarang, Indonesia.

Jeffrey, S. et al. (2006). Psikologi abnormal. Jakarta: Erlangga.

Kartono, K. (2000). Hygiene mental. Bandung: Mandar Maju.

Latifah, D., Zainuddin, M., \& Mulyana, N. (2015). Peran pendamping bagi orang dengan HIV/AIDS (ODHA). Prosiding Penelitian dan Pengabdian kepada Masyarakat, 2(3), 306-311.

Mustamir. (2007). Sembuh dan sehat dengan mukjizat al qur'an penerapan al quran sebagai terapi penyembuhan dengan metode religiopsikoneurologi. Yogyakarta: Lingkaran.

Naing, A. M. et al. (2004). Modul pelatihan konseling dan tes sukarela HIV (Voluntary conseling and test/VCT) untuk konselor profesional. Jakarta: Departemen Kesehatan RI, Direktoral Jendral Pelayanan Medik Direktorat Jendral Pemberantasan Penyakit Menular dan Penyakit Lingkungan.

Nursalam, \& Kurniawati, N. D. (2009). Asuhan keperawatan pada pasien terinfeksi HIV/AIDS. Jakarta: Salemba Medika.

Priyanto, A. (2009). Komunikasi dan konseling aplikasi dalam pelayanan kesehatan. Jakarta: Salemba Medika.

Potter, P., \& Perry, A. G. (2005). Fundamental keperawatan konsep, proses dan praktik (Yasmin Asih et al, Trans.). Jakarta: Penerbit Buku Kedokteran EGC. (Fundamental of nursing: Concepts, process, and practice. Original work published 1991).

Septiadi, B. (Ed.). (2017). Jumlah penderita HIV/AIDS di Rejang Lebong bertambah. Retrieved November 20, 2017, from website http://pedomanbengkulu.com/2017/11/jumlah-penderita-hiv-aids-di-rejanglebong-bertambah/.

Sutoyo, A. (2013), Bimbingan dan konseling islami (Teori dan praktik). Yogyakarta: Pustaka Pelajar.

Syahlan, et al. (1997). AIDS dan penanggulangannya. Jakarta: Departemen Kesehatan RI, Pusat Pendidikan Tenaga Kesehatan (PUSDIKNAKES).

Tomey, A.M. \& Alligood, M. R. (2006). Nursing theories and their work. 6th ed. St. Louis Missouri, USA: Mosby Elsevier. 
UNAIDS. (2006). The impact of AIDS on people and societies: Report on the global AIDS epidemic. Retrieved April 10, 2017, from website http://data.unaids.org/pub/report/2006/2006_gr_en.pdf.

Wulandari. (2000). Hubungan antara efikasi diri dan dukungan sosial dengan kepuasan kerja. (Unpublished undergraduate's thesis) Universitas Gadjah Mada, Yogyakarta, Indonesia. 